\title{
Clientelism and vote buying in local elections: A case study of Kartu Bintan Sejahtera
}

\author{
Klientelisme dan pembelian suara dalam pilkada: Studi kasus Kartu Bintan \\ Sejahtera
}

\author{
Tri Samnuzulsari ${ }^{1} \&$ Wayu Eko Yudiatmaja ${ }^{2}$ \\ ${ }^{1}$ Department of Sociology \\ ${ }^{2}$ Department of Public Administration \\ Faculty of Social and Political Sciences, Universitas Maritim Raja Ali Haji \\ Jalan Raya Dompak, Tanjungpinang, Riau Islands 29111, Indonesia \\ E-mail: wayuguci@umrah.ac.id / Phone:+62 81363121930
}

\begin{abstract}
This study finds out clientelism and vote buying on Kartu Bintan Sejahtera (KBS) in Bintan Regency, Riau Islands. The objective of this study is to understand the practices of clientelism and vote buying using $K B S$. This study based on case study research. The informants consist of General Election Commission of (KPUD) Riau Islands, candidates of the governor of Riau Islands 2015-2020, candidates of Bintan Regent 2015-2020, along with their supporting parties and campaigning team, and bureaucracy of the implementation of $K B S$. The main findings of this study suggest that $K B S$ is used as a clientelism and vote buying practices by the candidate of Riau Islands governor and Bintan Regent, 2015-2020 period. This study also finds that formal and informal political networks are utilized by the candidates as a clientelism and vote buying arenas. This study not only contributes to the literature of clientelism and vote buying, but also adds the literature of social policy in the context of Indonesian local politics setting. This study suggests that $K B S$ is used as a media to obtain the support of the voters in the election of governor of Riau Islands and regent of Bintan 2015-2020. All candidates capitalize the issue of $K B S$ to obtain the popularity. The patterns of the practice of clientelism and vote buying in $K B S$ is by using various media campaigns to promote the success story of $K B S$. Not only in formal campaign but also in informal campaign, they always promote $K B S$ as their success.
\end{abstract}

Keywords: clientelism; vote buying; regional general election; Kartu Bintan Sejahtera

\begin{abstract}
Abstrak
Studi ini mengkaji fenomena klientelisme dan pembelian suara dalam program Kartu Bintan Sejahtera (KBS), di Kabupaten Bintan, Provinsi Kepualauan Riau. Tujuan dari studi ini adalah untuk memahami praktik-praktik klientelisme dan pembelian suara dengan menggunakan KBS. Metode penelitian ini menggunakan pendekatan studi kasus dan informan terdiri dari calon gubernur Riau Islands 2015-2020, calon bupati Bintan 2015-2020, partai politik pendukungnya, tim sukses dan tim kampanye, dan birokrasi pelaksana program KBS. Hasil penelitian ini adalah program KBS digunakan sebagai praktik klientelisme dan pembelian suara oleh calon gubernur Riau Islands dan calon bupati Bintan 2015-2020. Penelitian ini juga menunjukkan bahwa jaringan politik formal dan informal digunakan oleh kandidat sebagai arena bagi praktik klientelisme dan pembelian suara. Studi ini tidak hanya berkontribusi bagi kajian mengenai klientelisme dan pembelian suara, tetapi juga memperkaya kajian mengenai kebijakan sosial dalam konteks politik lokal di Indonesia. Studi ini menunjukkan bahwa KBS digunakan sebagai media untuk mendapatkan dukungan pemilih dalam pemilihan gubernur Riau Islands dan Bupati Bintan 2015-2020. Semua kandidat memanfaatkan masalah KBS untuk mendapatkan popularitas. Pola praktik clientelism dan pembelian suara di KBS adalah dengan menggunakan berbagai kampanye media untuk mempromosikan kisah sukses KBS. Tidak hanya dalam kampanye formal tetapi juga dalam kampanye informal, mereka selalu mempromosikan KBS sebagai kesuksesan mereka.
\end{abstract}

Kata kunci: klientelisme; pembelian suara; pemilihan kepala daerah; Kartu Bintan Sejahtera

\section{Introduction}

This study explores the politics of social protection or social safety net policy at the local level in decentralization era. The main purpose of this study is to find out the political context of social 
safety program in the setting of Indonesia's local politics. There are two backgrounds underlying this study. The first, it is been a long time that Indonesia implements social protection policy. Since Old Order era, this policy has been implemented in Soekarno's administration during 1945-1966. In 1952, Soekarno initiated health insurance program for the private sector workers and in 1963 it's expanding towards government employees. However, because of the hyperinflation problem and economic stagnancy, this program was ineffective (Wie 2002).

Afterwards, in Order Baru era, social protection policies were continued to be implemented. Due to the impact of economic crisis in 1998, the New Order launched a policy, which was name Jaring Pengaman Sosial (JPS) as a response towards the economic crisis in Asia at that time (Sumarto \& Suryahadi 2001, Pritchett 2005). JPS spent 17,9 trillion country budget or equal to 30 percent governmental budget in 1998. The budget was allocated for food protection, financing governmental projects and providing social service to the society (Ananta \& Siregar 1999). Nevertheless, like other social protection policy, JPS unable to reach its target to reduce poverty rate because it was temporal and only for a short term.

Secondly, after the collapse of New Order, the next government still used social safety net program in the form of unconditional cash transfer (UCT) as an effort to reduce the poverty. During Susilo Bambang Yudhoyono (SBY) (2004-2014) periods, he launched a policy called by Bantuan Langsung Tunai (BLT) or Bantuan Langsung Sementara Masyarakat (BLSM), public health insurance (Jamkesmas) and rice for impoverished people (raskin) to compensate the increase of fossil fuel price (BBM). In 2005, BLT program was given to the 19,1 million impoverish households to maintain purchasing power of the society (Papanek \& Basri 2010). Meanwhile, raskin was begun in 2007, at that time government returned the authority of Badan Urusan Logistik (Bulog) to control the price of rice and distribute raskin (McCulloch \& Timmer 2008). In 2010, Bulog distributed 2.73 ton raskin. This amount decrease compared to the raskin distributed during 2009, 3.13 ton and 3.34 ton respectively (Suryahadi et al. 2010). Both BLT and raskin were aimed to improve the purchasing power of the societies as the impact of increasing fossil fuel price.

However, in fact, instead of helping the poor society, these policies were used by SBY regime and Democratic Party to gain popularity or vote gather in the presidential general election and legislative election in 2009 (Mietzner 2009a, Mietzner 2009b, Aspinall 2010). UCT policy launched by SBY was one of driver factor making the vote of Demokrat Party possible to increase in the legislative election, from 7.45 percent in 2004 to 20.85 percent in 2009 . The policy highly influences the voter preference in the election, primarily the voter from middle and lower class. An interesting finding of this situation discovered by Mietzner (2009a:4):

\footnotetext{
"The concurrent cash payments and reduced fuel prices were extremely popular in the lowincome segments of Indonesia society. While the middle class and business complained about the impact of the global financial crisis and inadequate government responses poorest Indonesian felt that after years of high inflation, costs were no falling. When asked in February 2009 whether their economic burden had become lighter or was still heavy after the government's cash payments and other pro-poor programs, 58 percent of respondents felt that their burden had become lighter, with only 24 percent saying it was still heavy".
}

Thirdly, the decentralization implemented since 1999 give an opportunity for the regional government (province/regency/city) to manage their government autonomously. It made be possible to the regional government to manage their own social protection policy at local level. A number of heads of local government give unconditional cash transfer to the poor societies in various forms, such as a scholarship for poor students, free healthcare, free school, livable house for poor people and so on. One of the breakthrough programs was Pemeliharaan Kesehatan Masyarakat Solo (PKMS) and Bantuan Pendidikan Masyarakat Kota Solo (BPMKS) implemented by Solo Mayor, Joko Widodo (Jokowi) (2005-2012). These programs were continued when Jokowi served as the Governor of capital city Jakarta (2012-2014). In Jakarta, this program was named Kartu Jakarta Pintar (KJP) and Kartu Jakarta Sehat (KJS). Because of his populist policies, Jokowi obtained sympathy from 
Indonesian people, helped him to win the Governor election for the second time in 2012 (Aspinall 2014a, Hamid 2014), and helped him to win presidential election later on (Aspinall \& Mietzner 2014).

Fourth, the successful story of Jokowi's is copied by other heads of local government. In Riau Islands, Ansar Ahmad, Regent of Bintan, released similar policy but with a different name, which was Kartu Bintan Sejahtera $(K B S)$. Ansar Ahmad, a politician of Golkar Party, is Bintan Regent for two period (2005-2010 and 2010-2015). He was nominated as the regent for the first period (2005-2010) with Mastur Taher. On the second period (2010-2015), he formed a pair with Khazalik from the same political party. In the middle of their administration (2013), Ansar Ahmad-Khazalik implemented a populist policy, called by Kartu Bintan Sejahtera (KBS). Currently, Ansar Ahmad is the Head of Regional Leadership Council (DPD) of Golkar of Riau Islands Province. KBS was rolled out through Bintan Regent regulation No. 21 the Year 2013 about the change of Regent's regulation No. 58 the Year 2012 about running the implementation of KBS facilities in Bintan Regency. KBS program was launched by Bintan Regent for the first time on January 3, 2013. As asserted by Ansar Ahmad, $K B S$ was a program to help poor society in education and health sector. The budget allocated for $K B S$ was Rp 615.6 billion, sourced from 60 percent of Regional Revenue and Expenditure Budget $(A P B D)$ in Bintan Regency, 15 percent of sharing the budget with Riau Islands Province, 20 percent from Government Budget $(A P B N)$ and five percent of society service funding (DKTM) from the companies in Bintan Regency (Batampos).

This phenomenon is an interesting issue to be discussed through the perspective of social protection policy in decentralization era. Generally, decentralization can result the process of formulating social safety program taking sides the society. In the other hand, in decentralization era, public policy could be manipulated by political elites for their personal, political and groups interests (Hadiz 2004, Robison \& Hadiz 2004). Social protection policy in decentralization era could have a similar situation. It can use as contestating arena of the interest of the elites to expand their power. In this context, it is interesting to be understood whether decentralization gives benefit to the societies through the formulating policy and program which is useful to the society. Furthermore, this study try to examine whether social policy at the local level truly oriented to the public interest or it only become a tools and arena for the interest of the elites.

The strategy of mobilizing the voters through social protection program was not a new study in the literature of political science and social policy. The study has been discussed by many scholars, for instances Subbarao et al (1997), Desposato (2002), Diaz-Cayeros \& Magaloni (2003), Brusco, Nazareno dan Stokkes (2004), Hall (2006), Magaloni, Diaz-Cayeros \& Estevéz (2007), Lindert et al (2007), Penfold-Becerra (2007), Stokes (2007), Sumarto (2007), Hall (2008), Zucco (2008), Fiszbien dan Schady (2009), Lomeli (2009), Rocha (2009), Bohn (2011), De La O (2013), Aytac (2014), Sumarto (2014), and Aspinall \& Sukmajati (2016). Most of the prior studies were conducted in Latin America, such as Brazil (Desposato 2002, Hall 2006, Penfold-Becerra 2007, Zucco 2008, Bohn 2011), Meksiko (Diaz-Cayeros 2008, De La O 2013), Argentina (Auyero 2000, Brusco et al 2004), Venezuela (Penfold-Becerra 2005, Hidalgo 2009). Majority of these studies clearly stated that the program is used as the practice of vote buying.

Surprisingly, the study conducted by many scholars focused on the politics of social policy in the setting of Latin American countries. In the context of Indonesia, only a limited number of the scholars have analyzed it, such as Sumarto (2014) and Aspinall \& Sukmajati (2016). Therefore, the present study fills the gap in recent literature about the political dimension of social policy in the setting of Indonesian case. Politically, the form and government system of Latin American countries are different with Indonesia. Many Latin American countries use federalism, whereas Indonesia use decentralization. In many ways, decentralization implemented in Indonesia has a significant difference with the federalized Latin American countries (Erawan 1999). Moreover, the design of social policy of Latin American countries also has a difference of type than social policy implemented in Indonesia. The difference lies in the policy character. The program of cash transfer 
in Latin American countries requires the using of its program only to buy the basic needs known as conditional cash transfers (CCT) (Lindert et al. 2007, Lomeli 2008, Soares, Ribas, \& Osório 2010, Soares 2011, Sugiyama 2011, Fenwick 2013). Meanwhile, BLT delivered in Indonesia was unconditional policy, except registered as recipient (Satriana 2008, and Dwiputri 2017).

\section{Research Method}

This study was a case study research by using explorative approach. Case study approach was used to explore the problem in certain cases or bounded system, which was unique and interesting either one or some cases together or multiple bounded systems in such detail. It also used the process of collecting the data directly and deeper using collecting data technique, such as observation, interview, audio-visual resource, documents and report. It were analysed in a descriptive way (Creswell 2007:73). The case of political dimensions of KBS in Bintan Regency was explored in a deeper way by investigating the problems relating to the research, understanding the tendency relating to the case, and generalizing it into a conclusion.

The data were gathered through interview, observation and collecting secondary data. The interview was conducted using the interview guidelines already prepared. The pattern of the interview was an indepth interview with dig the information deeper and the data obtained from the participants. The data and information gathered from the participants would be recorded and saved. Then, the researchers made the transcript, in order to make it easier to analyse. The data were also gathered through observing the phenomenon directly at the field related to the focus of this research. The findings obtained in the field will be recorded through fields notes. The documentation technique was also used as another way to collect secondary data through collecting data from a local newspaper in Tanjungpinang City, such as Haluan Kepri, Tanjungpinang Pos, Batam Pos dan Bintan News. The data collected from the newspapers were the news and political campaign of governor candidates of Riau Islands and Bintan regent candidates for 2015-2020 period. The news were collected into scrapbook and coding, as well as being interpreted in order to prove the practice of clientelism and vote buying in the election of Riau Islands governor and Bintan regent for the election period 2015-2020.

In order to understand and revealing the politics of $K B S$ in Bintan Regency, therefore the subject in this research could be classified based on certain category consisted of; politician (Ansar Ahmad dan his pair in Governor election of Riau Islands 2015-2020, Khazalik and his pair in election Regent election along with their competitor), the citizen of Riau Islands, public figure, youth figures, NGOs activist, academics, campaign team, political consultant, and political party proposing Khazalik in Regent Bintan election 2015-2020, executing bureaucracy of KBS, Regional Election Commission (KPUD) Kepri and KPUD Bintan Regency, and local mass media.

\section{The description of $K B S$}

$K B S$ program was established because of the phenomenon of the poverty in Bintan Regency. Based on the data of the Central Bureau of Statistics (BPS) of Riau Islands which was known that the total of poor people in Bintan Regency in 2013 was 149.120 or equal to 6.23 percent of its total population. In 2012 , recorded the total of poor people was 147.212 or 6.29 percent, in 2011 there are 145.057 (6.04 percent) and in 2010 the total143.020 or 7.33 percent. Although, overall the percentage of poor people decreasing, the reality is often different with the data.

$K B S$ is a program to overcome impoverishment held by the government of Bintan Regency since 2013. KBS is a identity card given to the head of poor family and head of the helpless family in Bintan Regency. This card is given based on the national parameter which has been set nationally about the indicator of a poor family. The implementation of $K B S$ program is conducted with the regulation of Bintan regent No. 84 the Year 2014 about the guidelines of the implementing KBS facility in Bintan Regency. In the practice, $K B S$ is divided into two categories, namely yellow and blue $K B S$. Yellow $K B S$ is used to cover healthcare fee and education fee. 
Table 1.

The total and percentage of poor population in Bintan Regency in 2010-2013

\begin{tabular}{cccc}
\hline Year & $\begin{array}{c}\text { The Total Population } \\
\text { Based on Gender } \\
\text { (M+W/Person) }\end{array}$ & $\begin{array}{c}\text { The Total of Poor } \\
\text { Population } \\
\mathbf{( 0 0 0 )}\end{array}$ & $\begin{array}{c}\text { The Percentage of } \\
\text { Poor Population (\%) }\end{array}$ \\
\hline 2010 & 143.020 & 10,5 & 7,33 \\
2011 & 145.057 & 9,3 & 6,04 \\
2012 & 147.212 & 9,3 & 6,29 \\
2013 & 149.120 & 9,3 & 6,23 \\
\hline \multicolumn{4}{r}{ Source: Central Bureau of Statistic of Riau Islands Province (2010-2013) }
\end{tabular}

Table 2.

Hospital and school of KBS partner

\begin{tabular}{cll}
\hline No & \multicolumn{1}{c}{ Health Facilities } & \multicolumn{1}{c}{ Education Facilities } \\
\hline 1 & Puskesmas Bintan District & SD/MI Bintan District \\
2 & RSUD Bintan District & SLTP/MtsN Bintan District \\
3 & RSUD Tanjungpinang & SLTA/MA Bintan District \\
4 & RSUP Riau Islands & Pesantren Madani Bintan District \\
5 & RSUD Riau Islands, Tanjung Uban & \\
6 & RSAL Midiyato & \\
7 & RSOB Batam & \\
8 & RSCM Jakarta \\
9 & RS Jiwa Panam, Pekanbaru \\
10 & RS Kanker Darmais & \\
11 & RS Jantung Harapan Kita, Jakarta & \\
\hline
\end{tabular}

Source: BPMPKB Bintan Regency

KBS can be used as the substitute of Surat Keterangan Tidak Mampu (SKTM) because there are many problems for the society to apply $S K T M$, for instance the difficulty of its requirement because of the red-tape bureaucracy. The criteria of $K B S$ recipient are must be Bintan Regency citizen or they have Bintan ID card, domiciled in Bintan for three consecutive years, the citizen with earnings under Rp1 million, the family with chronic illness and does not have health facility card or another education card.

Based on the data Community Empowerment Agency Women and Family Planning (BPMPKB), in 2014 , the total of $K B S$ recipient was 14.955 head of the family. The amount of the recipient of yellow $K B S$ was 9.224 and the total of the recipient of blue $K B S$ was 5.731 head of the family. The data of the recipient of $K B S$ were obtained from the poor citizen data released by the Central Bureau of Statistics and re-verify by the Government of Bintan Regency. These processes were conducted because KBS not only given to the poor head of the family but also given to another poor family already domiciled in Bintan Regency for three consecutive years.

For the society who did not receive $K B S$, requesting for submission of $K B S$ can be carried out personally. The head of the family who did not have a family certificate and Bintan id card have to fill the form or identification from $R T / R W$ in the form of a certificate of domicile and the statement letter of the poor. Afterwards, they have to bring those files to the district for applying $K B S$ and make sure their SKTM is signed by the head of the village. Then, the head of the village will return those files and bring it to the district to receive the approval of sub-district head. The head of family hand over the requirement completed to the secretariat of verification team of BPMPKB of Bintan Regency. The requirements must be completed in order to pass the verification are a photocopy of certificate, photocopy of id card, domiciled letter and SKTM. The files have to submit to the BPMPKB of Bintan 
Regency. Then, it were proposed and submitted to the verification team. The verification team will verify the application files whether it is already completed or not. Then, the team will decide whether the application already fulfil the requirement to issued $K B S$ card or not.

Table 3.

The recipient of KBS in 2014

\begin{tabular}{ccc}
\hline No & KBS Type & $\begin{array}{c}\text { Total } \\
\text { (Head of Family) }\end{array}$ \\
\hline 1 & Yellow KBS & 9.224 \\
2 & Blue KBS & 5.731 \\
\hline & Total & $\mathbf{1 4 . 9 5 5}$ \\
\hline
\end{tabular}

Source: BPMPKB Bintan Regency

Besides completing the file, the verification team will check the applicant names whether they appropriate with the criteria of $K B S$ recipient. If the names are not on the list of family who had to receive social aid, such as raskin, unlivable house $(R T L H)$, and other social aids, the verification team will visit the house of the head of family to make sure the real condition whether they are suitable to receive the $K B S$. If the requirements have been completed and the name is declared to suit the requirement, then the head of a family entitled to receive the $K B S$. The recipients file will given to the verification team of $B P M P K B$ to be printed. $B P M P K B$ contact and send it directly to each head of family or they can obtain it through their own sub-district.

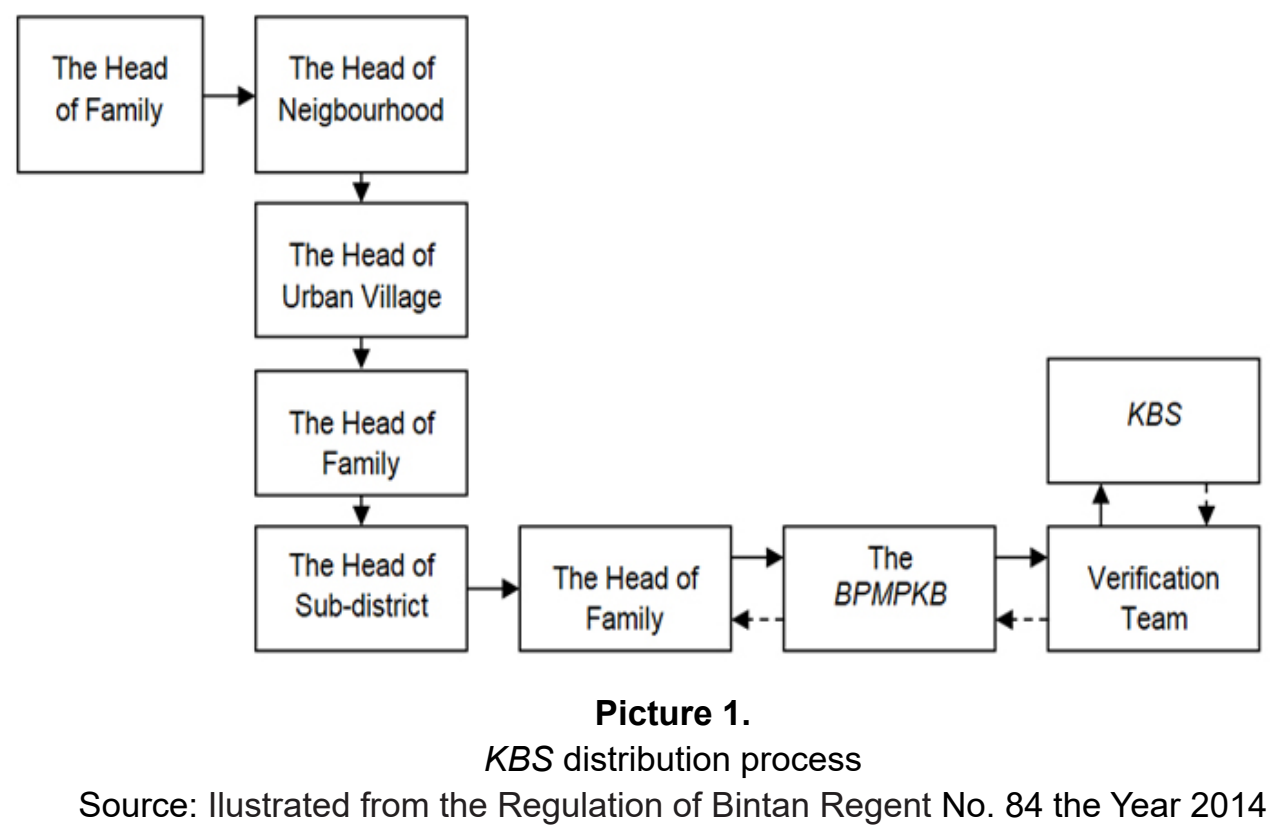

\section{Result and Discussion}

In the last general election, there were two candidates of the governor of Riau Islands and two candidates of Bintan regent. In Riau Islands, there were two candidates; Muhammad Sani dan Nurdin Basirun. In Bintan, there were also two candidates; Apri Sujadi-Dalmasri Syam.

$K P U$ of Riau Islands and $K P U$ of Bintan prepared the time and the steps of regional elections, from the process of registration to the announcement of the winner. The campaign process had been decided in December 2015 by KPU of Riau Islands. Nevertheless, every candidates have established their successful team, volunteers, and supporters. They used various ways to socialize their vision, mission, and campaign promises, including to inform the success stories of the candidates while 
leading. The existence of the supporting groups was the crucial point for the candidates competing in the regional elections because they need supporting group as voter-ghatered machine. It would be work hard to look for the support of the voters at the grass root.

Table 4.

The governor candidate Riau Islands 2015-2020

\begin{tabular}{ccc}
\hline No & Candidate & Supporters Party \\
\hline 1 & Muhammad Sani-Nurdin Basirun & $\begin{array}{c}\text { Partai Demokrat, Partai Nasional Demokrat, Partai } \\
\text { Persatuan Pembangunan, Partai Kebangkitan Bangsa, } \\
\text { Partai Gerindra }\end{array}$ \\
& $\begin{array}{c}\text { Poerya Respationo-Ansar Ahmad } \\
2\end{array}$ & PDI Perjuangan, Partai Amanat Nasional, Partai \\
Hanura
\end{tabular}

Source: Election Commission of Riau Islands Province (2015)

Table 5.

Bintan regent candidate $2015-2020$

\begin{tabular}{|c|c|c|}
\hline No & Candidate & Supporters Party \\
\hline 1 & Apri Sujadi-Dalmasri Syam & $\begin{array}{c}\text { Partai Demokrat, Partai Keadilan Sejahtera, Partai } \\
\text { Nasional Demokrat }\end{array}$ \\
\hline 2 & Khazalik-Indra Setiawan & $\begin{array}{c}\text { PDI Perjuangan, Partai Amanat Nasional, Partai } \\
\text { Hanura }\end{array}$ \\
\hline
\end{tabular}

This research found that $K B S$ is used as the practices of clientelism and vote buying by all of the candidates of governor of Riau Islands and regent of Bintan 2015-2020. In the gubernatorial election of Riau Islands, the practices of clientelism and vote buying were conducted by the candidate of vice governor, Ansar Ahmad, which was the former of Bintan regent 2010-2015. In addition, in the election of Bintan regent, it were practised by the candidate of Bintan regent, Khazalik, the former of vice regent of Bintan 2010-2015. In fact, they used $K B S$ as a tool to legitimize their success in order to obtain the sympathy and support from the voters.

The practice of clientelism and vote buying was conducted by using every media campaigns used by Ansar Ahmad and Khazalik. In fact, the campaigns in regional election consisted of two types, namely formal and informal campaigns. The formal campaign was a media and agenda of campaign arranged by the KPU, for instances direct campaign or open campaign and the debate of the candidates. Meanwhile, the informal campaign was a hidden-campaign did not arranged by the KPU, such as deploying the supporter secretly and using public facilities for unfair campaign activities, recitation groups, etc.

In the political campaign of Ansar Ahmad dan Khazalik, they never forget to blow up the issue of $K B S$ as one of the successful policy in their period. The campaign held by the candidates of the governor of Riau Islands consist of an opened dan closed campaigns. Muhamad Sani-Nurdin Basirun hold an closed campaign in Karimun Regency (11/28/2015) and opened campaign in Batam City (12/5/2015). Soerya Respationo-Ansar Ahmad held opened campaign in Batam City (11/29/2015) and Tanjungpinang City (12/5/2015). In every campaigns, both Soerya Respationo-Ansar Ahmad and Khazalik-Indra Setiawan always capitalize the issue of $K B S$ to attract the voters. $K B S$ is assumed as their successful program when they led Bintan.

On the other hand, both Ansar Ahmad and Khazalik, they always promote $K B S$ in every moment of togetherness with their supporters. $K B S$ is always repeated to be issued as one of the topic in their campaigns. Surprisingly, they use the formal and informal political networks as the arena of clientelism and vote buying. The formal network is the bureaucrats and the leader of bureaucracy who was still loyal to them. They are like a broker performing a propaganda mission to their subordinates. It is 
conducted by telling the success stories of the incumbent by word of mouth. Before commencement of regional election, there are two factions of the bureaucrats supporting Muhammad Sani-Nurdin Basirun and Soerya Respationo-Ansar Ahmad. As the result, the bureaucracy of the government of Riau Islands also divides into two factions called by "ayah's people" and "romo's people". Ayah's people refer to the person who support Muhammad Sani-Nurdin Basirun and romo's people are the person who supported Soerya Respationo-Ansar Ahmad. Even, the former of the secretary of the government of Riau Islands, Robert Iwan Loriaux is believed as romo's people. The network into the structure of the bureaucracy is controlled by the elites of the bureaucracy. Their mission is to organize the voters coming from public servants. They use their structural positions to affect the public servants in order to choose their candidates.

Table 6.

The campaign of Muhammad Sani-Nurdin Basirun

\begin{tabular}{|c|c|c|c|}
\hline Date & Campaign Type & Place & $\begin{array}{c}\text { Important } \\
\text { Person Who } \\
\text { Present }\end{array}$ \\
\hline Saturday, 28 November 2015 & Closed Campaign & $\begin{array}{c}\text { Novotel Hotel, } \\
\text { Karimun Regency }\end{array}$ & - \\
\hline Saturday, 5 December 2015 & Opened Campaign & $\begin{array}{c}\text { Baloi Kolam, Batam } \\
\text { City }\end{array}$ & Surya Paloh \\
\hline
\end{tabular}

Table 7.

The campaign of Soerya Respationo-Ansar Ahmad

\begin{tabular}{cccc}
\hline Date & Campaign Type & Place & $\begin{array}{c}\text { Important Person } \\
\text { Who Present }\end{array}$ \\
\hline Sunday, 29 November 2015 & Opened Campaign & Batam City & $\begin{array}{c}\text { Megawati Soekarno } \\
\text { Putri }\end{array}$ \\
Sabtu, 5 December 2015 & Opened Campaign & $\begin{array}{c}\text { Lapangan } \\
\text { Pamedan, } \\
\text { Tanjungpinang }\end{array}$ & $\begin{array}{c}\text { Ganjar Pranowo, } \\
\text { Adrian Napitupulu }\end{array}$ \\
\hline
\end{tabular}

Beside the formal network, there is the informal network used by Ansar Ahmad and Khazalik as the practice of clientelism and vote buying, such as through the coffee shops located in all region of Riau Islands. Even, long time before the campaign begins, they have had supported coffee shops. There are many coffee shops in Riau Islands because it has become the tradition of the Malays (Long 2013). As the tradition of the Malays who like to join together in the coffee shops, the coffee shops are the comfort place for drinking one cup of coffee and discussing (in Malays term called by berbualbual) various topics. The coffee shops are also believed by the candidates as not only the attract an informations but also to gain the voters. Both Ansar Ahmad and Khazalik, they have the coffee shops becoming the basis of their supporters. Ansar Ahmad and Soeryo Respationo have "Kedai Kopi Sore and AA". Khazalik and Indra Setiawan have Kedai Kopi Khawan. The name of these coffee shops stands for their name. The coffee shops are used by the candidates to carry out the practice of clientelism and vote buying. The practice of clientelism and vote buying is conducted by giving an amount of money, basic necessities, and etc to the visitors of their coffee shops. It is performed by the candidates, the volunteers, the successful and the campaign teams. By giving these donations, the candidates hope the voters are ready to choose them in the election.

The candidates of governor of Riau Islands and the candidate of Bintan regent also use mass media to promote $K B S$, not only the main stream media but also unpopular media, such as Haluan Kepri, Batam Pos, and Bintan News. It is used to campaign not only their vision, mission, and strategy, but also their successful policies. One of them is $K B S$. Interestingly, not only the incumbents but also their challenger use $K B S$ as a vote-gater strategy. The difference lies only in the way in campaigning it. If the incumbents promote the positive images of $K B S$, their challenger shows the facts about 
the weakness of KBS. By November 30, 2015 edition of Bintan News, political advertisement of Apri Sujadi-Dalmasri Syam and Khazalik-Indra Setiawan published side by side in one full page. Khazalik-Indra Setiawan make KBS as their political commodities. Meanwhile, Apri Sujadi-Dalmasri Syam campaign the lack of $K B S$ and they promised to improve it if they could be elected.

The findings of this study confirms several previous research (Desposato 2002, Brusco Nazareno \& Stokes 2004, Magaloni Diaz-Cayeros \& Estevéz 2007, Penfold-Becerra 2007, Zucco 2008, De La O 2013, Sumarto 2014) concluding that social policy is used by the elites to maintain their power. The practices of clientelism and vote buying conducted by the candidates of regional head government in this study are the effort to campaign $K B S$ as the proof of their success. The motive is to enhance their positive images that they are a populist candidate. It can be understood because nowadays, populism politics is rising in contemporary Indonesia (Mietzner, 2009a; Mietzner, 2015). In the context of populism politics, what the candidates do is a battle of image to obtain the support from the voters, rather than discourses (vision, mission, strategy) battle. The image battle is artifical campaign hiding the trully reality. Nevertheless, it is necessary to enhance the electability of the candidates. As Sahab's (2017) work who reviewed the political image conducted by Surabaya Major (2010-2015 and 20152020), Tri Rismaharini. Sahab (2017) revealed that everything carried out by Tri Rismaharini is a political image to show the populist image in the society. Nevertheless, the substantive problems are failed to be responded by Tri Rrismaharini.

\section{Conclusion}

This study suggests that $K B S$ is used as a media to obtain the support of the voters in the election of governor of Riau Islands and regent of Bintan 2015-2020. All candidates capitalize the issue of $K B S$ to obtain the popularity. The patterns of the practice of clientelism and vote buying in $K B S$ is by using various media campaigns to promote the success story of $K B S$. Not only in formal campaign but also in informal campaign, they always promote $K B S$ as their success. The formal campain used by the candidates as the media to carry out the practices of clientelism and vote buying is direct campaign and debate among the candidates. Yet, the informal campaign is such as bureaucracy networks, the coffee shops, and the mass media. This study also reveals that actually not only the incumbents but also their challengers also use $K B S$ as a vote-gater strategy. This fact shows that social policy is the rational choice to reach the power. This study fruitfuls to understand clientelism and vote buying in social policy in the context of Indonesian local politics.

\section{References}

Ananta A \& Siregar R (1999) Social safety net policies in Indonesia. ASEAN Economic Bulletin, 16 (3):344-359.

Aspinall E (2010) Indonesia 2009: Democratic triumph and trials. Southeast Asian Affairs 102-125.

Aspinall E (2014a) Health care and democratization in Indonesia. Democratization, 21 (5):803-823.

Aspinall E \& Meitzner M (2014) Indonesian politics in 2014: Democracy's close call. Bulletin of Indonesian Economic Studies, 50 (3):347-369.

Aspinall E \& Sukmajati M (2016) Electoral dynamics in Indonesia: Money politics, patronage and clientelism at the grassroots. Singapore: NUS Press.

Auyero J (2000) The logic of clientelism in Argentina: An ethnographic account. Latin American Research Review, 35 (3):55-81.

Aytac SE (2014) Distributive politics in a multiparty system: The conditional cash transfer program in Turkey. Comparative Political Studies, 47 (9):1211-1237.

Batampos (2013) Bintan Luncurkan Kartu Bintan Sejahtera. Batampos, 03 Januari 2013. [Accessed 24 March 2015]. http://batampos.co.id/03-01-2013/bintan-luncurkan-kartu-bintan-sejahtera/. 
Bohn SR (2011) Social policy and vote in Brazil: Bolsa familia and the shifts in Lula's electoral base. Latin American Research Review, 46 (1):54-79.

Brusco V, Nazareno M \& Stokes SC (2004) Vote buying in Argentina. Latin American Research Review, 39 (2):66-88.

Creswell JW (2007) Qualitative Inquiry and Research Design: Choosing Among Five Approaches (Second Edition). Thounsand Oaks, CA: Sage Publications.

De La OA (2013) Do conditional cash transfers affect electoral behavior?: Evidence from a randomized experiment in Mexico. American Journal of Political Science, 57 (1):1-14.

Desposato SW (2002) How vote buying shapes the political arena?. Paper prepared for the Comparative Politics of Vote Buying Conference. Massachusetts Institute of Technology (MIT), Cambridge, Massachusetts, August 26-27.

Diaz-Cayeros A \& Magaloni B (2003) The politics of public spending: Part i-the logic of vote buying. Paper for the World Bank Development Report.

Diaz-Cayeros A (2008) Electoral risk and redistributive politics in Mexico and the United States. Studies in Comparative International Development, 43 (2):129-150.

Dwiputri IN (2017) The impact of the unconditional cash transfer program (BLT) on cigarette consumption in Indonesian society. Journal of Indonesian Economy and Business, 32 (2):138150 .

Erawan IKP (1999) Political reform and regional politics in Indonesia. Asian Survey, 39 (4):588-612.

Fenwick TB (2013) Stuck between the past and the future: Conditional cash transfer programme development and policy feedbacks in Brazil and Argentine. Global Social Policy, 13 (2):144-167.

Hadiz VR (2004) Decentralization and democracy in Indonesia: A citique of neo-institutionalist perspectives. Development and Change, 35 (4):697-718.

Hamid A (2014) Jokowi's populism in the 2012 Jakarta gubernatorial election. Journal of Current Southeast Asian Affairs, 33 (1):85-109.

Hilgado M (2009) Hugo Chavez’s “petro-socialism”. Journal of Democracy, 20 (2):78-92.

Lindert K, Linder A, Hobbs J, \& De la Brière B (2007) The nuts and bolts of Brazil's Bolsa Familia program: Implementing conditional cash transfers in a decentralized context. Social Protection Discussion Paper of the World Bank.

Lomeli EV (2008) Conditional cash transfers as social policy in latin America: An assessment of contributions and limitations. Annual Review of Sociology, 34:475-498.

Lomeli EV (2009) Conditional cash transfer programs: Achievements and illusions. Global Social Policy, 9 (2):167-171.

Long, NJ (2013) Being Malay in Indonesia: Histories, Hopes, and Citizenship in the Riau Archipelago. Singapore: NUS Press.

Magaloni B, Diaz-Cayeros A, \& Estevez F (2007) Clientelism and Portofolio Diversification: A Model of Electoral Investment with Applications to Mexico. In: H Kitschelt \& SI Wilkinson (eds). Patrons, Clients, and Policy: Patterns of Democratic Accountability and Political Competition (pp. 182-204). Cambridge: Cambridge University Press.

McCulloch N \& Timmer P (2008) Rice policy in Indonesia: A special issue. Bulletin of Indonesian Economic Studies, 44 (1):33-44.

Mietzner M (2009a) Indonesia's 2009 elections: Populism, dinasties and the consolidation of the party system. Working Paper for the Lowy Institute for International Policy, Sidney. 
Mietzner M (2009b) Political opinion polling in post-authoritarian Indonesia: Catalyst or obstacle to democratic consolidation. Bijdragen tot de Taal-, Land- en Volkenkunde 165 (1):95-126.

Mietzner M (2015) Reinventing Asian populism: Jokowi's rise, democracy, and political contestation in Indonesia. Policy Studies, 72:1-74.

Papanek GF \& Basri MC (2010) The Impact of the World Recession on Indonesia and an Appropriate Policy Response: Some Lessons for Asia. In: A Bauer \& M Thant (eds). Poverty and Sustainable Development in Asia: Impacts and Responses to the Global Economic Crisis (pp. 13-50). Manila, Philippines: Asian Development Bank.

Pemerintah Kabupaten Bintan (2014) Laporan keterangan pertanggungjawaban (LKPJ) akhir tahun anggaran 2013 Kabupaten Bintan. Dokumen yang tidak dipublikasikan.

Penfold-Becerra M (2005) Social funds, clientelism and redistribution: Chavez's “misiones" programs in comparative perspective. Working Paper.

Penfold-Becerra M (2007) Clientelism and social funds: Evidence from Chávez's misiones. Latin American Politics and Society, 49 (4):63-84.

Peraturan Bupati Bintan No. 21 Tahun 2013 tentang Perubahan atas Peraturan Bupati Nomor 58 Tahun 2012 tentang Pelaksanaan Fasilitas Kartu Bintan Sejahtera di Kabupaten Bintan.

Pritchett L (2005) The political economy of targeted safety nets. Social protection discussion paper of the Social Protection Unit Human Development Network of the World Bank.

Rocha C (2009) Developments in national policies for food and nutrition security in Brazil. Development Policy Change, 27 (1):51-66.

Robison R \& Hadiz VR (2004) Reorganising Power in Indonesia: The Politics of Oligarchy in Age of Markets. London: Routledge Curzon.

Sahab A (2017) Realitas citra politik Tri Rismaharini. Masyarakat, Kebudayaan dan Politik, 30 (1):2034.

Satriana S (2009) Impact assessment of the 2008 unconditional cash transfer programme (BLT) in Indonesia. Master Thesis at the Maastricht Graduate School of Governance, Netherlands.

Soares, FV (2011) Brazil’s Bolsa Família: A review. Economy \& Political Weekly, 46 (21):55-60.

Soares FV, Ribas RP, \& Osório RG (2010) Evaluating the impact of Brazil's Bolsa Familia: Cash transfer programs in comparative Perspective. Latin American Research Review, 45 (2):173190.

Stokes SC (2007) Is Vote Buying Undemocratic?. In: FC Schaffer (ed). Elections for Sale: The Causes and Consequences of Vote Buying (pp. 117-145). Colorado: Lynne Rienner.

Subbarao K, Bonnerjee A, Ezemenari K, Braithwaite J, Graham C, Carvalho S, \& Thompson A (1997) Safety Net Programs and Poverty Reduction: Lessons from Cross-Country Experience. Washington, D.C: World Bank.

Sugiyama NB (2011) The Diffusion of the conditional cash transfer programs in the Americas. Global Social Policy, 11 (2-3):250-278.

Sumarto M (2007) Social safety nets and economic transition in Indonesia: paradox of social services? Journal of Administration and Governance, 2 (1):54-60.

Sumarto M (2014) Perlindungan Sosial dan Klientelisme: Makna Politik Bantuan Tunai dalam Pemilihan Umum. Yogyakarta: Gadjah Mada University Press.

Sumarto S \& Suryahadi A (2001) Principles and approaches to targeting with reference to the Indonesian social safety net. Paper presented at ASEAN-Australia Social Safety Net Project in Jakarta, Indonesia, May 22-23. 
Suryahadi A, Yumna A, Raya UR, \& Marbun D (2010) Review of government's poverty reduction strategies, policies, and programs in Indonesia. Research Report of SMERU Research Institute.

Wie TK (2002) The Soeharto Era and After: Stability, Development and Crisis, 1966-2000. In: H Dick, VJH Houben et al. (eds). The Emergence of a National Economy: An Economic History of Indonesia, 1800-2000 (pp. 194-243). Crows Nest, NSW: Allen \& Unwin.

Zucco C (2008) The president's new' constituency: Lula and the pragmatic vote in Brazil's 2006 presidential elections. Journal of Latin American Studies, 40 (1):29-49. 